\title{
Occupational Asthma Occurrence Analysis and Factor Factors Affecting on Furniture Workers in Balongrejo Village Kecamatan Berbek Nganjuk
}

Fitra Handika Hutama

Magister of Public Health Program of Stikes Surya Mitra Husada Kediri

Email:

fitrahandika93@gmail.com
Received: March 12, 2019

Accepted : April 13, 2019

Published : May 10, 2019

\begin{abstract}
Wood working or furniture workers are workers at risk of exposure to dust, whether derived from sawmill assembly or wooden welding, thus at risk of developing occupational diseases such as respiratory diseases such as asthma. Lack of self-discipline workers to use self-protection tool (APD) in the form, mask is one of the factors that influence the incidence of respiratory diseases with the main symptoms of cough. This happens because the workers inhale sawdust or wooden dust. This study is an obeservational study with cross sectional design. Samples and respondents are furniture workers in Balongrejo village, Berbek sub-district, Nganjuk regency, as many as 120 people taken by cluster random sampling of 94 people. The statistic test used is logistic regression. The result of statistical test shows that significant value $<0.05$ means $\mathrm{H} 1$ is accepted and $\mathrm{H} 0$ is rejected. This means that there is an influence between smoking, the use of personal protective equipment (masks), and the temperature of the workspace against occupational asthma events, and a significant value> of 0.05 means that $\mathrm{H} 1$ is rejected and $\mathrm{HO}$ accepted This means no effect on the occurrence of occupational asthma, of influencing factors above the most dominant factor affecting the occurrence of occupational asthma in furniture workers is smoking and the use of personal protective equipment (masks). Efforts that can be done in overcoming this problem is the active role of Disnakertrans of Nganjuk Regency to make the order regulation to the owner of Furniture Trade Enterprise to provide PPE to the workers, the active role of health officer in giving health counseling for the furniture workers.
\end{abstract}

Keywords: Masks, occupational asthma, furniture workers

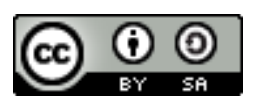

This is an open-acces article distributed under the terms of the Creative Commons Attribution-ShareAlike 4.0 International License.

\section{INTRODUCTION}

The development of technology and industry today is very fast, one of the existing industries in Indonesia is the household furniture industry. Home appliances are very diverse kinds, in terms of materials of its type is very much and varied, ranging from glass, iron, plastic, even to the wood, the way the processing of various products are of course also different. Wooden furniture making will undergo several stages of the process, from raw wood, then semi-finished, to finished furniture and to the hands of consumers, this long process will certainly require a great deal of furniture involved, 
various types of process can produce dust, either domestic industry, or construction (Indah Rahmatiah, 2015).

According to Dwina Roosmini, 2015 Dust is part of the airbone contaminant or pollutants in the air working environment, in other words this dust is very easy inhaled by the respiratory tract, especially for workers who have history of asthma, or workers who do not have asthma, allergens that can cause airway obstruction. Various diseases can arise in industrial jobs that contain industrial dust, especially at fairly high levels, such as pneumoconiosis, silicosis, asbestosis, hemosiderosis, bisinosis, bronchitis, occupational asthma, lung cancer, and others. In addition, according to MOH (2009), in general asthma risk factors are divided into two groups, namely genetic factors and environmental factors. Allergens are triggers or triggers that are common to patients. Room dust mites, mold spores, cockroaches, animal skin flakes such as dogs, cats and others that can cause asthma attacks in sensitive patients. These allergens are usually inhaled allergens, although occasionally food and drink can cause an attack (Sundaru, 2007).

Allergens from outside the room include dust, pollen, and other irritating ingredients are perfume, household spray and smell of paint (Rengganis, 2008). Occupational factors Occupational asthma There are 2 types of asthma, the first most common (approximately 90\% of cases) are occupational asthma with latent periods dependent on the causative agent. This type is usually mediated by IgE, which means that workers have been exposed to allergens at work over a period of time before developing into allergies and asthma. The second type is occupational asthma in the absence of a latent period (about 10\% of cases). This usually occurs because of high levels of exposure by chemicals, air or irritating odors. Exposure usually occurs after an accident or leak in the workplace (Bradshaw, 2010).

Various other air pollution variations, cigarette smoke, vehicle fumes, increased ozone, zulfur dioxide, and nitrogen dioxide can trigger asthma attacks (Lewis, et al., 2007). Patients with asthma are very sensitive to these substances let alone smoke containing combustion products in the form of sulfur dioxide and photochemical oxide. Cigarette smoke may be air pollution that occurs indoors apart from mosquito repellent sprays and hair sprays that can trigger asthma attacks. Patients who do not smoke can get an asthma attack because it is in a room full of cigarette smoke. Patients with children more often get an asthma attack if at home there is a smoking (Sundaru, 2007).

The lung disease is divided into 3 parts: 1. Due to organic dust, such as cotton dust (Bissinosis), grain worker.s disease, wood dust 2. Due to inorganic dust (pneumoconiosis) eg silica dust (Silicosis) asbestosis dust, tin dust (Stannosis). 3. Lung disease due to irritant gas, 3 pollutants that most affect lung health are sulfur dioxide (SO2), nitrogen dioxide (NO2) and ozone (O3). When occupational lung disease has occurred, there is generally no specific and effective treatment to cure it (Armaidi Darmawan, 2013). Some potential occupational exposures lead to occupational asthma such as high concentration welding fumes, isocyanates, and exposure of various toxic materials (aluminum, cadmium, metals, ammonia, cigarette smoke, wood dust, cotton, and endotoxins) (Bagus Artana, 2013)

From the results of the predecessor study which was conducted on 21 December 2016, the furniture company in Balongan Village, Berbek Sub-district, Nganjuk Regency on 5 Trade Enterprises and 10 workers resulted 8 people often complained of shortness and cough when working, 2 people complained coughing when working, in addition to where they work the use of personal protective equipment while working is still not done. While data from Puskesmas Pembantu Desa balongrejo get data in January 2018 there are 17 patients complain of cough and tightness.

Occupational asthma is a disease characterized by breath-flow disorders and bronchial hyperacicitis that occur due to a situation in the work environment and does not occur in stimuli outside the work area. Work-related asthma generally refers to two circumstances, namely occupational asthma and work-aggravated asthma. Occupational asthma is a disease characterized by variable airflow resistance and / or hyper responsiveness associated with inflammation caused by occupational causes and conditions, or in other words, occupational asthma is occupational asthma. While work-aggravated asthma is characterized by the worsening of asthma previously suffered by the patient previously due to exposure and / or special environment (Ida Bagus Ngurah Rai, 2016)

According to Ida Bagus Ngurah Rai, 2016 Management of asthma in collaboration with the management of asthma in general. Pharmacologically, occupational asthma therapy has the same principle of handling, that is, achieving controlled asthma status. In contrast to non-pharmacological 
management, the handling approach aims to reduce or eliminate exposure to occupational asthma. This is slightly different in the case of work-aggravated asthma, where total avoidance of exposure material is not absolutely necessary, but otherwise appropriate and optimal pharmacological treatment is needed.

The ERS Consensus and RCP 2012 formulated some recommendations related to management for occupational asthma cases. Patients, doctors, and employers should be informed that continuous exposure to materials will worsen symptoms of asthma and airway obstruction. Avoiding exposure materials in total provides the highest possible improvement, but can not eliminate the asthma. Use of personal protective equipment (especially breathing shields) is one of the main safeguards, especially in long-term exposure and severe cases of asthma.

\section{MATERIALS AND METHODS}

This research is an exploratory survey research using cross-sectional approach. With a quantitative analytic design. Cross-sectional research is a type of study that emphasizes the time of measurement of independent variable data, and is dependent only once at the time of study (Nursalam, 2015). Of course not all research subjects should be observed on the same day or time, but both independent and dependent variables are assessed only once.

\section{RESULTS}

\section{Characteristics of the Subject Table 1.}

Characteristics of respondents in this study include Age, Residence, and Last Education

\begin{tabular}{cccc}
\hline No & Karakteristik & $\mathbf{\Sigma N}$ & $\mathbf{\Sigma \%}$ \\
\hline \multirow{4}{*}{1} & Umur (th) & 3 & \\
& $20-30$ & 18 & 3.2 \\
& $30-40$ & 40 & 19.1 \\
& $40-50$ & 33 & 42.6 \\
& $50-60$ & & 35.1 \\
2 & Tempat Tinggal & 89 & 94.7 \\
& Desa Balongrejo & 5 & 5.3 \\
\hline \multirow{4}{*}{3} & Luar Desa Balongrejo & & \\
\multirow{3}{*}{ Pendidikan Terakhir } & 9 & 9.6 \\
& SD & 40 & 42.6 \\
& SLTP & 45 & 47.9 \\
\hline & SLTA & & $\mathbf{1 0 0}$ \\
\hline
\end{tabular}

From the above table of 94 respondents, most of them are 40-50 years old $(42.6 \%$,). Almost all respondents live in Balongrejo Village (89.77.7\%), while from the last education most of the respondents are $40(42.6 \%)$.

Table 2 Factor analysis that influenced the occurrence of occupational asthma in furniture workers in Balongrejo Village, Berbek Sub-district, Nganjuk District, on December 22-31, 2017. 
Variables in the Equation

\begin{tabular}{|c|c|c|c|c|c|c|c|}
\hline & & $\mathrm{B}$ & S.E. & Wald & df & Sig. & $\operatorname{Exp}(\mathrm{B})$ \\
\hline \multirow{6}{*}{ Step $1^{\mathrm{a}}$} & Smoking & 1.323 & .395 & 11.232 & 1 & .001 & 3.753 \\
\hline & Usage mask & -1.832 & .421 & 18.96 & 1 & .000 & .160 \\
\hline & Long time work & -.421 & .812 & .269 & 1 & .604 & .656 \\
\hline & Part of work & .567 & .288 & 3.861 & 1 & .049 & 1.762 \\
\hline & Temperature of work & 2.020 & .592 & 11.623 & 1 & .001 & 7.537 \\
\hline & Constant & 2.997 & 3.943 & .578 & 1 & .447 & 20.018 \\
\hline \multirow{5}{*}{ Step $2^{\mathrm{a}}$} & Smoking & .646 & .561 & 1.325 & 1 & .003 & 1.908 \\
\hline & Usage mask & -1.976 & .528 & 14.031 & 1 & .000 & .139 \\
\hline & Long time work & -.695 & 1.044 & .444 & 1 & .505 & .499 \\
\hline & Part of work & 1.127 & .480 & 5.511 & 1 & .019 & 3.086 \\
\hline & Constant & 3.890 & 3.226 & 1.454 & 1 & .228 & 48.908 \\
\hline \multirow{4}{*}{ Step $3^{\mathrm{a}}$} & Smoking & .661 & .554 & 1.424 & 1 & .007 & 1.936 \\
\hline & Usage mask & -1.947 & .514 & 14.329 & 1 & .000 & .143 \\
\hline & Part of work & 1.169 & .477 & 6.011 & 1 & .014 & 3.218 \\
\hline & Constant & 2.428 & 2.299 & 1.115 & 1 & .291 & 11.334 \\
\hline \multirow{3}{*}{ Step $4^{\mathrm{a}}$} & Smoking & -1.948 & .380 & 11.232 & 1 & .001 & 6.753 \\
\hline & Usage mask & -2.133 & .505 & 17.855 & 1 & .000 & 2.528 \\
\hline & Constant & 4.668 & 1.407 & 11.007 & 1 & .001 & 106.510 \\
\hline
\end{tabular}

Based on the above table shows that, of the five variables that affect the occurrence of occupational asthma in furniture workers in Balongrejo Village Nganjuk regency, obtained the results of three variables that affect the occurrence of occupational asthma. From the three variables, the two most dominant variables influence the occurrence of occupational asthma, that is smoking with the result ( $\mathrm{p}=0.001$; OR $=3.753$ ) means that if the furniture is smoked then they will be 4 times more likely to be occupational asthma than non-smokers, protective equipment (masks), with the result ( $\mathrm{p}=$ 0.000 ; $\mathrm{OR}=2,528$ ). This means that if a furniture worker smokes, then the furniture worker is likely to be occupied by occupational asthma, whereas if the furniture workers use personal protective equipment (masks) while working, and do not smoke then they can have an opportunity to avoid the occupatinal asthma risk as much as 4 times.

\section{DISCUSSION}

\section{The influence of age on the use of mask self-protector tool on furniture workers in Balongrejo} Village, Berbek District Nganjuk District

Based on this research from 94 respondents got the result, most of respondent aged 40-50 Years never wear personal protective equipment (mask) when working as many as $24(60.0 \%)$. From the statistical test results obtained $\mathrm{p}$ value 0.032 which means < from 0.05 so that $\mathrm{H} 1$ accepted and $\mathrm{H} 0$ rejected, which means there is influence between age with the use of personal protective equipment (mask). However, this study differs from the results of a study conducted by Yuli Hendra 2011, with the title of Some Factors Affecting With the Practice of Protecting Personal Equipment (Apd) On Radiographers In Radiology Installation Hospital In Semarang City, which states there is no influence between age and use of PPE (mask) with the result $p=0.484$.

Many opinions are varied with respect to age numbers. Hurlock 1992, limiting middle age is around 40 - 60 th. It divides 2 phases, ie middle age middle-aged (40-50 years) and advanced middle 
age (50 -60 th). Whereas according to Erikson's developmental theory, the main developmental task in middle age is to achieve generativeity, generativeity is a more mature and broader sense of care than intimacy because it has "generalized" to other groups, especially the next generation. When with intimacy we engage in relationships in which we expect a reciprocal of our partners, then with generativity we do not expect rewards (the desire to care for and guide others). Mature adults can achieve generativeity with their children through guidance in social interaction with the next generation. If adults are failing to reach generativeity stagnation will occur. Stagnation is the opposite of generativeity that is limited concern for ourselves, no caring for others. A person who experiences stagnation is no longer productive to society because they can not see anything other than whether it benefits themselves or not (Papilia E. Diane, 2008).

From the results of interviews with furniture workers who are in Balongrejo Village District Berbek Nganjuk regency, they declared reluctant to use masks while working due to feel uncomfortable and hesitate. Besides, there is no punishment from the owner of the place of business if when the workers do not use the mask while working.

\section{The influence of recent education on the use of personal protective equipment (mask) on furniture workers in Balongrejo Village, Berbek District Nganjuk District}

Based on this research, it was obtained from 94 respondents that most of respondents 26 (52.0\%) have junior high school, and never use mask when working. From the statistical test results obtained $\mathrm{p}$ value 0.008 , which means < from 0.05 so $\mathrm{H} 1$ accepted and $\mathrm{H} 0$ rejected, which means there is influence between the last education with the use of personal protective equipment (mask). The results of this study is different from the research conducted by Muhammad Rizky Andriyanto with the title of Effect of Predisposing Factor With Behavior of APD Usage In Production Unit Worker I PT Petrokima Gresik, Year 2016. The result of this research is $p=0.069$ which means $>0.05$.

According Notoatmodjo (2005), education is defined as each of the influence, effort, protection and assistance that will be addressed to students who process into adulthood. It can be interpreted indirectly to have a slight influence on the behavior of the workforce.

The educational programs provided to workers in the field of occupational safety and health can provide a fundamental foundation so as to require effective participation in finding solutions to problems that are in the workplace. One's education affects the way of thinking in the face of work. There are many factors that can affect the increase in work productivity, but the educational factor is one that has a very big influence. The higher the level of education of a person, the greater the possibility of labor can work and carry out their work well (Madyanti, 2012). Education is defined as formal education achieved or obtained dibangku school. Formal education is a very important capital because with education a person has the ability and can easily develop themselves in the field of work (Handoko, 2008). Frederick J. Mc Donald expressed his opinion that education is a process whose goal is to change the nature of human beings or learners. The destruction of the use of personal protective equipment (masks) by the furniture workers in Balongrejo Village, Berbek Subdistrict, Nganjuk Regency is in addition to the background of junior high school education, they also feel embarrassed when working with masks, they claim to work and have to use masks as if people who is ill.

\section{The influence of the last education on the occurrence of occupational asthma in furniture workers in Balongrejo Village, Berbek District Nganjuk District.}

Based on this research, the results obtained from 94 respondents almost half of the respondents $36(46.8 \%)$ last junior high school, and experienced the occurrence of occupational asthma. From the statistical results obtained $\mathrm{p}$ value 0.026 , which means < from 0.05 so that $\mathrm{H} 1$ accepted and $\mathrm{HO}$ rejected which means there is influence between the last education with the occurrence of occupational asthma. John Dewey said education is a process of experience. Because life is growth, then education means helping the inner growth of man without being limited by age. The process of growth is the process of adjustment in each phase and adds skills to one's development through education. Pieget has the view that every organism has an inherent tendency to adapt to the environment, it may be in the course of development over a period of time that new experiences do 
not correspond legally to the psychological structure within the individual, and can not be assimilated into existing schemes, the scheme must be changed, expanded and adapted to the facts gained from the new experience (Mohammad Ali, 2010).

Occurrence of occupational asthma can not be directly felt by the impact of the furniture workers today, but the impact is felt later, this understanding should be known by the furniture workers in Balongrejo Village, Berbek District, Nganjuk District.

\section{The influence of smoking on occupational asthma occurrences in furniture workers in Balongrejo Village, Berbek District Nganjuk District}

Based on the results of this study showed that from 94 respondents it is known that most of 52 respondents $(67.5 \%)$ smoked, with moderate category and experienced occupational asthma events. From the test results using statistical regression logistic value $\mathrm{p}=0.001$ and $\mathrm{OR}=3.753$. This implies that if a furniture worker smokes it will have a greater chance of being exposed to occupational asthma compared to non-smoking furniture workers. Because the $\mathrm{p}$ value $<0.005$, then $\mathrm{H} 1$ accepted and Ho rejected, which means there is the influence of smoking with occupational asthma occurrences in furniture workers in the Village Balongrejo Berbek District, Nganjuk. The results of this study are similar to the results of previous research conducted by Ana Nailis, Et All, 2014 with the title of factors that affect the incidence of asthma in furniture workers in Mulyoharjo wood industry, Semarang, Central Java in 2014, with the result there is influence between smoking with incidence of asthma ( $\mathrm{p}=0,007, \mathrm{OR}=4,600 \mathrm{CI} 95 \%)$. Smoking is the act of lighting a cigarette with a fire then smoking the cigarette and exhaling (May Ahyanti, 2013). Really 2014, says the toxic and harmful substances contained in cigarettes are nicotine, this nicotine will make the heartbeat work faster and harder, the heart muscle frequency increases, causing increased blood pressure. Next is the tar according to Marjun 2012, tar is a hydrocarbon substance that is sticky and easily attached to the lungs, in addition tar also contains carcinogens. Besides, there is also carbon monoxide which is a dangerous gas contained in vehicle exhaust fumes. CO replaces the $15 \%$ oxygen that should be carried by red blood cells. CO can also damage the inner lining of the blood vessels and elevate the fat deposits in the blood vessel walls, causing blocked blood vessels. Aiman, 2006 states smoking is not a major factor in the occurrence of occupational asthma, but a worker who smokes may be more at risk for occupational asthma.

Smokers are someone who likes to smoke, called active smokers if the person is actively smoking, and is called a passive smoker if the person only receives cigarette smoke instead of doing his own smoking activity (KBBI, 2012). Another definition of smokers are those who smoke every day for a minimum period of six months during which their life is still smoking when the survey is conducted (Octafrida, 2011). In order to overcome these problems, the role of health workers, especially those in Puskesmas is very necessary, the provision of health education to the public about the behavior of life, clean and healthy (PHBS) should always be given regularly, poster installation on the dangers of smoking should also be installed in the area work, not just furniture workers but in other industrial or work areas. Furniture workers are expected to be able to understand and understand that their behavior has been wrong, so that the furniture workers in Balongrejo Village, Berbek Subdistrict, Nganjuk Regency, can periodically stop smoking.

The influence of the use of personal protective equipment (masks) against the occurrence of occupational asthma in furniture workers in Balongrejo Village, Berbek District, Nganjuk Regency

From the results of this study it is known that most of 49 respondents $(63.6 \%)$ never use masks while working and experienced occupational asthma events. From the statistical test result using logistic regression statistic in get result $p=0.000 \mathrm{OR}=2,528$, which means $<$ from 0.05 so that $\mathrm{H} 1$ accepted and $\mathrm{H} 0$ rejected, which means there is influence between the use of personal protective equipment (mask) to occupational asthma occurrence at worker furniture in Balongrejo Village, Berbek District, Nganjuk Regency. This implies that if the furniture worker does not use a mask when working, the furniture worker is likely to be occupational asthma, the result is similar to the results of the 2009 Khumaidah study, on the Analysis of Factors Affected by Interference Lung Function In 
Furniture Workers PT Kota Jati Furnindo Suwawal Village District Mlonggo Jepara district with the results $\mathrm{p}$ value $=0.002$ value $\mathrm{X} 2=6.656$ and $\mathrm{OR}=8,571(95 \% \mathrm{CI}=0.907-80,993)$. A worker or employee is defined as a person working in an agency or institution or organization. In Big Indonesian.

Dictionary (2011) stated that "Employees are workers, employees". Employees have rights and obligations, the right of employees is to get compensation, get protection either physically or legally from the relevant institution, have health and safety guarantee in work. While the employer is an employee, a company, a business entity employing labor by providing wages or other forms (Law 13 of 2003 on employment), further to the 1970 law, the employer is in addition to the provision of protective equipment self (mask) must be provided by the owner of the place of business.

Furniture entrepreneurs in Balongrejo Village, Berbek District, Nganjuk District, have not provided masks for their workers. The role of the Health Office as health institutions should play an active role in efforts to improve the prevention of occupational diseases, in addition to the Disnakertrans as Intansi which becomes the container of workers are expected to be more active in order to prevent occupational diseases as well, as well as monitoring, guidance to business actors who deviate from labor laws and regulations, applicable in Indonesia.

\section{Influence of length of service to occupational asthma occurance at furniture worker in Balongrejo Village, Berbek Subdistrict, Nganjuk Regency}

Based on the results of this study it is known that almost all 64 respondents $(83.1 \%)$ have a working period of more than 5 years. From statistic test result using logistic regression statistic get result 0604 with $\mathrm{OR}=656$, so $\mathrm{H} 1$ is rejected and $\mathrm{H} 0$ accepted which means there is no influence between length of service with occupational asthma occurrence at furniture worker in Balongrejo Village Kecamatan Berbek Nganjuk. This study is also in line with previous research conducted by yalekah in 2007 that there is no influence between the duration of work with respiratory disorders in lime industry workers with the result $\mathrm{p}$ value 0.192 . Then also supported by research from viandari 2008 , which states there is no influence between the length of service with the incidence of asthma in workers in the wheat factory, with a value of $p$ value 0,520 . This is in contrast to research conducted by Riska Riski Year 2013, on the Effect of Working Period and Disposable Disposable Mask with Shortness of Occasions at Workers Composting at PT. Zeta Agro Corporation Brebes. The results of this study were variables related to the occurrence of shortness of breath is the variable working period with $\mathrm{p}$ value $0.032(<0.05)$ and variable disposable mask use with $\mathrm{p}$ value $0.006(<0.05)$. Working hours are time to do work can be done day and night, in this case 7 working hours in 1 day or 40 working hours in 1 week for 6 working days in 1 week. (Act No.13 of 2003 on Manpower). Workers who work $\geq 10$ years are at increased risk of occupational asthma compared with workers who work $<10$ years. While Ririn 2013, declared the length of service is a period or duration of the worker work somewhere.

The furniture workers in Balongrejo Village, Berbek District Nganjuk District only do the furniture work if they get the order, this means not every day they always make furniture. In addition, at the place of study the furniture workers work part time, meaning that in one day sometimes they not only do the work in the field of furniture making only, but also do other jobs such as farming, gardening and so forth. However, they remain at risk of being affected by their work as furniture workers.

The influence of the work on the occurrence of occupational asthma in furniture workers in Balongrejo village, Berbek sub-district, Nganjuk regency.

From the results of this study is known almost half of the 48 respondents (52.1\%) work on sanding and spraying melamine. From the statistical test results logistic regression obtained results $\mathrm{p}$ value 0.049 and $\mathrm{OR}=1.762$ which means $\mathrm{H} 1$ accepted $\mathrm{H} 0$ rejected which means there is influence between the work with occupational asthma occurrences in furniture workers in Balongrejo Village Berbek District, Nganjuk District. This study is similar to the research conducted by Tisnawati, 2014 which states there is influence between the work with the incidence of asthma in the workers burner brick in the village of Babadan Temanggung Central Java with $\mathrm{p}$ value 0.004 and $\mathrm{OR}=3.276$. 
The workplace is any room either open or closed either on the ground or in the air that is often entered by people and there is a danger. (Suma'ur 2013). While Siti Salami 2015, more mengkerucutkan workplace becomes a part of work. The work section is a division of work to be completed by the worker who is responsible for it. The division of labor in this furniture worker may be based on customs and needs (Afandi, 2013).

The process of making the existing furniture of Balongrejo Village, Berbek District Nganjuk District, is still widely done on vast place, but the ventilation is less than $20 \%$. So the particles from sanding and spraying melamine can not be directly carried away by the wind. In this research, three working parts of furniture workers in Balongrejo Village, Berbek District Nganjuk District, were cutting, assembling, and sanding and spraying of melamine. At the cutting part of the dust produced is not much, the particles of dust in the cutting part is still in the form of a large particle, so it can still be disraed by the respiratory tract of the furniture workers. However, in the sanding and spraying section of melamine, the furniture workers in Balongrejo Village, Berbek District Nganjuk District, sanding lots are also done manually and using the machine, so that the dust particles produced are also numerous and in the form of smaller particles.

\section{The influence of working room temperature on the occurrence of occupational asthma in furniture workers in Balongrejo Village, Berbek District, Nganjuk Regency}

Based on this research obtained the results of most respondents 67 (72.3\%) working with the temperature of the workspace is not eligible. From the result of statistic test of logistic regression obtained the result of p-value 0.001 which means <from 0.05 and $\mathrm{OR}=7.537$ meaning that the furniture worker working on the unqualified temperature will have an opportunity 8 times the risk for occupational asthma, so $\mathrm{H} 1$ is accepted and $\mathrm{H} 0$ rejected, which means there is influence between the working room temperature to the occurrence of occupational asthma, the furniture workers in Balongrejo Village, Berbek District, Nganjuk District, but this study contradicts the research that has been done by Aryanto Purnomo, 2014 with the title Analysis of Wood Dust Exposure Against Asthma Disease Symptoms in Informal Sector Workers, the results of this study states there is no effect of working room temperature on the incidence of asthma, with the result $\mathrm{p}$ value 0.064 . Temperature of workspace in accordance with Kepmenkes standard no. 1405 / Menkes / SK / XI / 02.17 is $18{ }^{\circ} \mathrm{c}$ to $30^{\circ} \mathrm{c}$, higher workspace temperatures will make the dust particle last longer in the air, and it will make the workers more at risk to inhale dust particles (Makara Kesehatan, 2010).

The completion of furniture making by the furniture workers in Balongrejo Village Ngekuk District Berbek Nganjuk done in place that apply esbes, so the temperature is very hot at all, ranging from $310 \mathrm{C}$, in addition there is no application of wet spray method to wet the work area.

\section{CONCLUSION}

In this research can be concluded as follows:

1. There is an influence between smoking with occupational asthma occurrences in furniture workers in Balongrejo Village, Berbek District, Nganjuk District $(\mathrm{p}=0.001 \mathrm{OR}=3.753)$.

2. There is influence of the use of personal protective equipment (mask) with occupational asthma occurrence on furniture workers in Balongrejo Village, Berbek District, Nganjuk Regency $(\mathrm{p}=0.000$ $\mathrm{OR}=1.60$ ).

3. There is no influence between the length of service with occupational asthma occurrences in furniture workers in Balongrejo Village, Berbek District, Nganjuk Regency $(\mathrm{p}=0.604 \mathrm{OR}=6.56)$.

4. There is no influence between the work with occupational asthma occurrences on furniture workers in Balongrejo Village, Berbek District, Nganjuk Regency $(\mathrm{p}=0.49 \mathrm{OR}=1.762)$.

5. There is influence between workspace temperature with occupational asthma occurrence on furniture workers in Balongrejo Village, Berbek District, Nganjuk Regency ( $\mathrm{p}=0.001 \mathrm{OR}=7.537$ ).

6. Factors affecting occupational asthma occurrences in furniture workers in Balongrejo Village, Berbek District, Nganjuk District smoking $(\mathrm{p}=0.001 \mathrm{OR}=3.753)$, use of personal protective equipment (mask) $(\mathrm{p}=0.000 \mathrm{OR}=160)$, room temperature work $(\mathrm{p}=0.001 \mathrm{OR}=7.537)$. 
7. The most dominant factor affecting occupational asthma occurrence on furniture workers in Balongrejo Village, Berbek Subdistrict, Nganjuk Regency is the use of personal protective equipment (mask) $(\mathrm{p}=0.000 \mathrm{OR}=1.60)$.

\section{SUGGESTION}

1. For Respondents.

To be able to use personal protective equipment (masks) while doing the work, so that the occurrence of occupational asthma can be reduced the number of events.

2. For the place of study.

Furniture entrepreneurs should provide personal protective equipment (masks) to give to their workers free of charge, so that workers are expected to be free from asthma.

Furniture entrepreneurs should apply wet flush techniques to the work area, to minimize dust particles hovering in the air.

Entrepreneurs should not do sanding and spraying of melamine in a closed work area, but done in an open work area, so that the dust from sanding and particles from melamine can be directly carried by the wind. The existence of no smoking rules for all furniture workers, during the work.

3. For Educational Institutions.

Continue to conduct research in the field of Occupational Safety (OSH), to prevent any other factors that may be the originator of occupational asthma diseases.

4. For the Government of Nganjuk Regency.

Should the agency office in this case is the Office of Manpower and Transmigration Nganjuk, can provide insight to the furniture entrepreneurs in all Nganjuk regency in general, and especially on the entrepreneurs in Balongrejo Village, District Berbek Nganjuk District, for all workers when working is supplied and using personal protective equipment (mask).

5. For further researchers.

With the limitations in this study, the next researcher is expected to develop this research to find out other trigger factors of occupational asthma.

\section{REFERENCES}

Afandi. (2013). Kebutuhan area kerja dan peruntukan bagi pekerja pada area kerja. Edisi Ke satu Jakarta; Angkasa.

Depkes. ( 2015). Profil kesehatan Indonesia. Jakarta: Departemen Kesehatan RI.

Kepmen Tenaga Kerja RI. (2017). Tentang diagnosa dan pelaporan penyakit akibat kerja. Kementrian Tenaga Kerja Indonesia; Jakarta.

Kepmenkes. (2002). Tentang Persayaratan dan Tata Cara Penyelenggaraan Kesehatan Lingkungan Kerja. Kemenkes; Jakarta.

Kepmenkes RI. (2008). Tentang Pengendalian Penyakit Asma. Kemenkes; Jakarta.

Khumaidah. (2009). Analisis Faktor-Faktor Yang Berhubungan Dengan Gangguan Fungsi Paru Pada Pekerja Mebel PT Kota Jati Furnindo Desa Suwawal Kecamatan Mlonggo Kabupaten Jepara. Jurnal K3, ISSN:20983017. 
Mohammad, A. (2010). Psikologi Remaja Perkembangan Peserta Didik. Jakarta: PT. Bumi Aksara.

Ngurah Rai, I., B., \& Artana, B. (2016). Asthma Metting Comprehenssive Approach Of Asthma. Denpasar Bali; RSUP Sanglah Denpasar.

Nursalam. (2015). Metodologi Penelitian Keperawatan. Surabaya: Salemba.

Permenakes RI. (2017). Tentang Petunjuk Teknis Pendaftaran, pesertaan, pembayaran iuran, dan pelayanan jaminan sosial tenaga kerja. Kementrian Tenaga Kerja Indonesia; Jakarta.

Permen Tenaga Kerja dan Transmigrasi RI. (2017). Tentang pemeriksaan kesehatan tenaga kerja dalam penyelenggaraan keselamatan kerja. Permenaker; Jakarta.

Peraturan Presiden RI. (2014). Tentang pengesahan Convention cocerning the promotional framework for occupational safety and healt. Kemenaker; Jakarta.

Ririn, A. (2011). Hubungan perilaku merokok dengan kejadian asma pada pekerja mebel di wilayah kerja Boyolali. Boyolali; Press Boyolali.

Riska, R. (2013). Pengaruh Masa Kerja dan Pemakaian Masker Sekali Pakai dengan Kejadian Sesak Napas pada Pekerja bagian Composting di PT. Zeta Agro Corporation Brebes. UNNES; Semarang.

Tisnawati. (2014). Kejadian Asma Pada Pekerja Pembakar Batu Bata Di Desa Babadan Temanggung Jawa Tengah. UGM; Jogja. 